\title{
Risk Factors of Dengue Fever: Application of PRECEDE - PROCEED Model
}

\author{
Kanthi Devi Ayuningtyas ${ }^{1,2)}$, Setyo Sri Rahardjo3), Bhisma Murti²) \\ ${ }^{1)}$ School of Health Sciences Patria Husada, Blitar, East Java \\ 2)Masters Program in Public Health,UniversitasSebelasMaret \\ 3) Faculty of Medicine, UniversitasSebelasMaret
}

\begin{abstract}
Background: Dengue infection is one of the main health problems in more than 100 tropical and subtropical countries. This study aims to analyze the factors that play a role in the occurrence of dengue fever cases by applying the PRECED - PROCEED model.

Subjects and Method:This was an analytic observational study with a case control design. The study was conducted at 8 sub-districts in Sukoharjo, Central Java, from May to July 2018. A sample of 200 study subjects was selected for this study by fixed disease sampling, comprising 50 peoples with dengue fever and 150 peoples without dengue fever. The dependent variables were dengue fever. The independent variables were intention, attitude, education, dengue fever prevention, family income, and sanitation. The data were collected by questionnaire and analyzed by path analysis run on Stata 13 .

Results: The risk of dengue fever was directly reduced by good environmental sanitation $(b=-$ $1.32,95 \% \mathrm{CI}=-2.09$ to $-0.54, \mathrm{p}=0.001)$ and good prevention behavior $(\mathrm{b}=-2.61,95 \% \mathrm{CI}=-3.55$ to 1.67, $\mathrm{p}<0.001)$. The risk of dengue fever was indirectly affected by intention, attitude, education, and family income.

Conclusion: The risk of dengue fever is directly reduced by good environmental sanitation and good prevention behavior. The risk of dengue fever is indirectly affected by intention, attitude, education, and family income.
\end{abstract}

Keywords: dengue fever, preventive behavior, environmental sanitation, PRECEDE-PROCEED model

\section{Correspondence:}

Kanthi Devi Ayuningtyas. School of Health Sciences Patria Husada, Blitar. Jl. Sudanco Supriyadi No 168, Blitar, East Java. Email: kanthideviayuningtyas@gmail.com. Mobile: o8125266956.

\section{BACKGROUND}

Dengue is an infectious disease caused by one of the four types of dengue virus, namely DENV-1, DENV-2, DENV-3, and DENV-4. The four serotypes of the virus are transmitted by Aedes mosquitoes (Guzman and Harris, 2015). The Aedes mosquito species that transmits the dengue virus is Aedes aegypti which is commonly found in dense urban environments (Pang et al., 2017) and Aedes albopictus which are forest mosquito species that breed in water collected in tree holes or shelter other naturally occurring (Rezza, 2012). Infection caused by all four types of dengue virus can cause various levels of severity in humans, starting from asymptomatic infections, acute fever that cannot be distinguished from fever due to other diseases, dengue fever, to dengue hemorrhagic fever and lifethreatening dengue shock syndrome (Bäck and Lundkvist, 2013).

World Health Organization (2018) reported an increase in the number of dengue infection cases from 2.2 million in 2010 to 3.2 million in 2015. Dengue infection is now an endemic disease in more than 100 countries, covering the regions of 
Journal of Epidemiology and Public Health (2019), 4(1): 37-46

https://doi.org/10.26911/jepublichealth.2019.04.01.05

Africa, America, Eastern Mediterranean, Southeast Asia, and Western Pacific. In endemic countries, the burden of disease due to dengue infection becomes a large problem. In Southeast Asia an estimated 2.9 million cases and 5,906 deaths occur each year (Shepard, Undurraga and Halasa, 2013). In 2017, the number of dengue cases in Indonesia reached 59,047 with 444 cases of death. Central Java ranked third for dengue cases cumulative incidence $(21.60$ per 100,00o population) and the first order for the case fatality rate $(1.24 \%)$ among the provinces on the island of Java in 2017. Sukoharjo is one of the regencies in Central Java with a case fatality rate (1.63\%) above Central Java (Dinas Kesehatan Provinsi Jawa Tengah, 2018).

Research on dengue case predictions in Sukoharjo regency was carried out in 2016 using a Geographical Information System (GIS) model which reported findings that an increase in dengue fever cases was influenced by an increase in land expansion, population density, rainfall and river flow (Kusumawati et al., 2016). In addition to these environmental conditions, several behavioral-related factors also become determinants in dengue cases, as reported by Nurrochmawati et al. (2017), it is stated that the presence of bushes around the house, the presence of mosquito larvae, clean water, clothing depends, control of the place where mosquitoes develop, and larvae monitoring activity are predicted to be a trigger factor for dengue cases.

Study related to dengue infection by applying the PRECEDE-PROCEED model was conducted by Chanyasanha, Guruge and Sujirarat (2015) who analyzed the factors that influence the behavior of preventing dengue infection. In contrast to these studies, in this study the purpose of using the PRECEDE-PROCEED model is to describe and analyze risk factors for dengue fever through path analysis, so that factors can be identified, both directly and indirectly.

\section{SUBJECTS AND METHOD \\ 1. Research Design}

This was a case-control study conducted in Sukoharjo, Central Java, from May to July 2018.

\section{Population and samples}

A sample of 200 study subjects were taken from 8 sub-districts using fixed disease sampling, consisting of 50 people who had suffered from dengue fever and 150 people who had never had dengue fever. The dengue fever data obtained from Sukoharjo District Health Office.

\section{Research Variables}

The dependent variable was dengue fever. The independent variables were environmental sanitation, preventive behavior, intention, self-efficacy, attitude, education level, and family income.

\section{Operational Definition of Variables}

Dengue fever was defined as case of dengue infection reported by the Sukoharjo District Health Office (including case originating from Puskesmas and Hospitals). Environmental sanitation is rural environmental sanitation in the form of a percentage of healthy home percentage taken from the local health centers report. Preventive behavior is a behavior to prevent the proliferation of mosquito larvae and protect themselves from adult mosquito bites, according to Circular No. PM.01.11/ MENKES/591/2016 concerning Implementation Eradication of $3 \mathrm{M}$ Plus Mosquito Nests.

Intention was defined as the tendency to prevent and control dengue fever by means of $3 \mathrm{M}$ Plus (drain and close water reservoirs, recycle used goods that have the potential to hold water, and make additional efforts that are useful to protect them- 
selves from mosquito bites). The measurement scale was continuous, but for the purpose of data it was transformed into dichotomous, coded o for low intention and 1 for strong intention.

Self-efficacy was the belief in the ability to carry out preventive behavior, which is owned by the subject. The measurement scale was continuous, but for the purpose of data it was transformed into dichotomous, coded o for low self-efficacy and 1 for strong self-efficacy.

Attitude was interpreted as the study subject's response to prevent and control dengue fever. The measurement scale was continuous, but for the purpose of data it was transformed into dichotomous, coded o for negative attitude and 1 for positive attitude.

Education level was defined as the highest level of formal education achieved by the study subject. The measurement scale was categorical, but for the purpose of data analysis, it was transformed into dichotomous, coded $\mathrm{o}$ for $<$ senior high school and 1 for $\geq$ senior high school.

Family income was defined as the average amount of family income every month in rupiah. The measurement scale was continuous, but for the purpose of data analysis, it was transformed into dichotomous, coded o for $<\mathrm{Rp}$ 2,000,000 and 1 for $\geq$ Rp 2,000,000.

\section{Data Analysis}

Univariate analysis was used to describe the frequency distribution and characteristics of study subjects. Furthermore multivariate analysis using path analysis was carried out to determine the direct or indirect influence in the relationship between study variables.

\section{Research Ethics}

The ethical clearance in this study was obtained from the Ethics Commission for Health Research, Faculty of Medicine, SebelasMaret University, Surakarta No 47 / UN27.6 / KEPK / 2018.

\section{RESULTS}

\section{The characteristic of study subjects} Characteristics of study subjects are described in Table 1 . The proportion of study subjects with age less than or more than 36 years is almost the same. Meanwhile, based on the gender, most of the study subjects were women. As many as $2 / 3$ of the samples reached education $\geq$ senior high school and had family income $\geq R p$ 2,000,000.

Table 1. Study subject characteristics

\begin{tabular}{|c|c|c|c|c|c|c|}
\hline \multirow{2}{*}{ Characteristics } & \multicolumn{2}{|c|}{ Case } & \multicolumn{2}{|c|}{ Control } & \multicolumn{2}{|c|}{ Total } \\
\hline & $\mathbf{N}$ & $\%$ & $\mathbf{N}$ & $\%$ & $\mathbf{N}$ & $\%$ \\
\hline \multicolumn{7}{|l|}{ Age (years) } \\
\hline$<36$ & 27 & 54 & 75 & 50 & 102 & 51 \\
\hline$\geq 36$ & 23 & 46 & 75 & 50 & 98 & 49 \\
\hline \multicolumn{7}{|l|}{ Gender } \\
\hline Male & 12 & 24 & 12 & 8 & 24 & 12 \\
\hline Female & 38 & 76 & 138 & 92 & 176 & 88 \\
\hline \multicolumn{7}{|l|}{ Education } \\
\hline$<$ Senior high school & 31 & 62 & 40 & 26.7 & 71 & $35 \cdot 5$ \\
\hline $\begin{array}{l}\geq \text { Senior high school } \\
\text { Occupation }\end{array}$ & \multicolumn{3}{|c|}{ Occupation } & $73 \cdot 3$ & 129 & 64.5 \\
\hline Not working & 31 & 62 & 62 & 41.3 & 93 & 46.5 \\
\hline Working & 19 & 38 & 88 & 58.7 & 107 & $53 \cdot 5$ \\
\hline \multicolumn{7}{|c|}{ Family Income (Rupiah) } \\
\hline$<2,000,000$ & 31 & 62 & 46 & 30.7 & 77 & 38.5 \\
\hline$\geq 2,000,000$ & 19 & 38 & 104 & 69.3 & 123 & 61.5 \\
\hline
\end{tabular}


Journal of Epidemiology and Public Health (2019), 4(1): 37-46

https://doi.org/10.26911/jepublichealth.2019.04.01.05

\section{Path Analysis}

Multivariate analysis with path analysis model was carried out using STATA 13. The path analysis model was made in accordance with the application of the PRECEDEPROCEED model in the framework of the research concept, illustrated in Figure 1.

Variables in the model consisted of 6 endogenous variables and 2 exogenous variables. The degree of freedom (df) is 15 which means that $\mathrm{df}$ is over identified so that the path analysis can be carried out.

Dengue fever was directly affected by environmental sanitation and preventive behavior. The risk of getting dengue fever decreased with good environmental sanitation $(\mathrm{b}=-1.32,95 \% \mathrm{CI}=-2.09$ to $-0.54, \mathrm{p}=$ $0.001)$ and better preventive behavior ( $\mathrm{b}=-$ $2.61,95 \% \mathrm{CI}=-3.54$ to $-1.67, \mathrm{p}<0.001$ ).

Dengue fever was indirectly affected by intention, attitude, self-efficacy, education, and family income.
Good environmental sanitation increased with high family income $\geq \mathrm{Rp}$ $2,000,000(\mathrm{~b}=0.51,95 \% \mathrm{CI}=-0.06$ to 1.09 , $\mathrm{p}=0.080$ ). High family income increased dengue fever prevention behavior $(b=0.63$, $95 \% \mathrm{CI}=0.01$ to $1.24, \mathrm{p}=0.047$ ).

Dengue fever preventive behavior was associated with intention. Strong intention to prevent dengue fever increased the likelihood of having better prevention behavior $(\mathrm{b}=1.39,95 \% \mathrm{CI}=0.77$ to 2.01 , $\mathrm{p}<0.001$ ).

Intention to prevent dengue fever was affected by strong self-efficacy $(b=0.75$, $95 \% \mathrm{CI}=0.09$ to $1.40, \mathrm{p}=0.024)$ and positive attitude $(\mathrm{b}=1.87,95 \% \mathrm{CI}=1.21$ to $2.52, \mathrm{p}<0.001$ ).

Attitude was affected by education level $\geq$ senior high school $(\mathrm{b}=1.05,95 \% \mathrm{CI}=$ 0.45 to $1.65, p=0.001$ ). High family income increased with high education level $(\mathrm{b}=$ $1.87,95 \% \mathrm{CI}=1.23$ to $2.50, \mathrm{p}<0.001$ ).

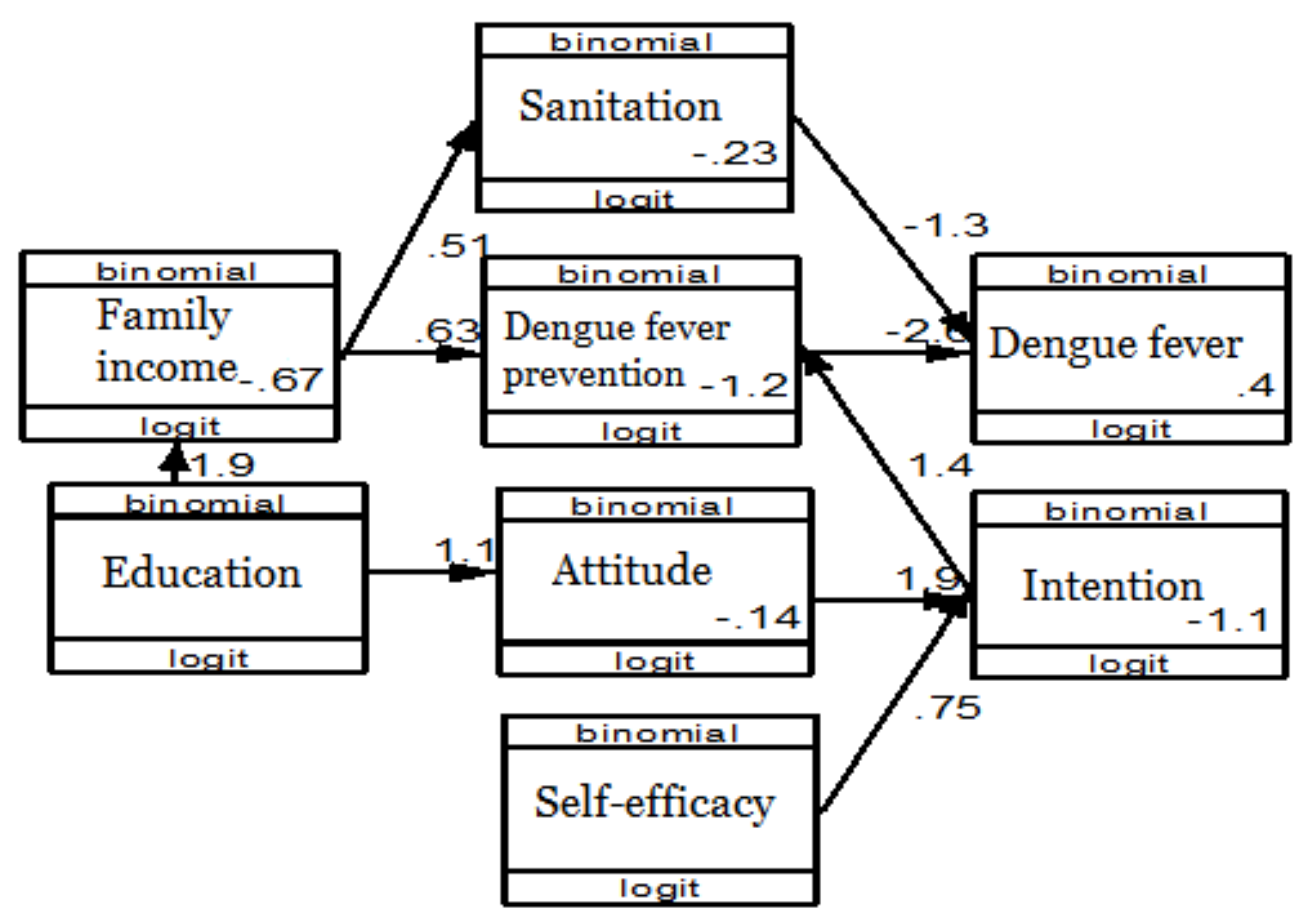

Figure 1. Path Analysis of Dengue Fever Risk Factor 
Table 2. Path Analysis Results of Dengue Fever Risk Factors

\begin{tabular}{|c|c|c|c|c|c|c|}
\hline \multirow[b]{2}{*}{ Dependent Variable } & & \multirow[b]{2}{*}{ Independent Variable } & \multirow[b]{2}{*}{ b } & \multicolumn{2}{|c|}{$95 \% \mathrm{CI}$} & \multirow[b]{2}{*}{$\mathbf{p}$} \\
\hline & & & & $\begin{array}{l}\text { Lower } \\
\text { Limit }\end{array}$ & $\begin{array}{l}\text { Upper } \\
\text { Limit }\end{array}$ & \\
\hline \multicolumn{7}{|l|}{ Direct Effect } \\
\hline Dengue Fever & $\leftarrow$ & $\begin{array}{l}\text { Good environmental } \\
\text { sanitation }\end{array}$ & -1.32 & -2.09 & -0.54 & 0.001 \\
\hline Dengue Fever & $\leftarrow$ & $\begin{array}{l}\text { Good dengue fever } \\
\text { preventive behavior }\end{array}$ & -2.61 & $-3 \cdot 55$ & -1.67 & $<0.001$ \\
\hline \multicolumn{7}{|l|}{ Indirect Effect } \\
\hline $\begin{array}{l}\text { Good environmental } \\
\text { sanitation }\end{array}$ & $\leftarrow$ & High family income & 0.51 & -0.06 & 1.09 & 0.080 \\
\hline $\begin{array}{l}\text { Good dengue fever } \\
\text { preventive behavior }\end{array}$ & $\leftarrow$ & Intention & 1.38 & 0.78 & 2.01 & $<0.001$ \\
\hline $\begin{array}{l}\text { Good dengue fever } \\
\text { preventive behavior }\end{array}$ & $\leftarrow$ & High family income & 0.63 & 0.007 & 1.24 & 0.047 \\
\hline Intention & $\leftarrow$ & Positive attitude & 1.87 & 1.21 & 2.52 & $<0.001$ \\
\hline Intention & $\leftarrow$ & High self-efficacy & 0.75 & 0.09 & 1.40 & 0.024 \\
\hline Attitude & $\leftarrow$ & High education level & 1.05 & 0.45 & 1.65 & 0.001 \\
\hline Family Income & $\leftarrow$ & High education level & 1.87 & 1.23 & 2.51 & $<0.001$ \\
\hline \multicolumn{7}{|l|}{$\mathrm{N}$ observation $=200$} \\
\hline \multicolumn{7}{|l|}{ Log likelihood $=-696.83$} \\
\hline \multicolumn{7}{|l|}{$\mathrm{AIC}=1423.67$} \\
\hline $\mathrm{BIC}=1473.14$ & & & & & & \\
\hline
\end{tabular}

\section{DISCUSSION}

Martini et al. (2018) stated that dengue infection was affected by a low level of hygiene and poor sanitation. In addition to these environmental factors, some behaviors also contributed to the occurrence of dengue infection cases. As reported by Nurrochmawati et al. (2017), which stated that having an open water reservoirs and the habit of hanging clothes was positively increased the risk of dengue infection.

The correlation of environmental factors and behavioral factors with dengue infection cases was also stated by Brady et al. (2014), based on the investigation conducted in Brazil. The results of the investigation concluded that the behaviors of storing water at home and lack of basic sanitation were significantly correlated to dengue infection cases in the hospital.

The PRECEDE-PROCEED model was a model used for planning and evaluating health behavior change programs. This model was not only described the deter- minant of a condition (outcome) but also explained how an intervention could affect the determinants and outcomes (Glanz, Rimer and Viswanath, 2008). The application of the PRECEDE-PROCEED model in this study was actually not in accordance with the purpose of modeling, but it was expected to be a guide for the implementtation of behavior change programs for the prevention and the control of dengue fever.

Some of the constructs of the PRECEDE-PROCEED model in this study were predisposing and enabling factors that were predicted to have an effect on environmental sanitation and the preventive behavior of dengue fever. Predisposing factors were the characteristics of a person who allowed him/her to behave, which in this study were attitude, self-efficacy, intention and educational level variables. The enabling factor in this study was described as a family income variable, which was a factor that allowed a person to take preventive action of dengue fever, or 
Journal of Epidemiology and Public Health (2019), 4(1): 37-46

https://doi.org/10.26911/jepublichealth.2019.04.01.05

also a factor that directly affected the environmental sanitation. Furthermore, the path analysis used in this study provided an overview of the relationships between variables in these factors.

Socio-economic status in the form of educational levels, types of work, and income that correlate with each other would eventually have an effect on health. This was possible because of its relation to material resources. In addition, people with a high level of education were more likely to have high income and a healthy lifestyle (Calixto and Anaya, 2014).

The results of the analysis in this study indicated a correlation between the level of education and family income with dengue fever cases. This was in accordance with a study by Abeyewickreme et al. (2012), which stated thatthe incidence of dengue infection was positively correlated with the level of education. Educated society reduced the risk of dengue infection. This might be due to increased awareness and ability to conduct preventive practices.

Meanwhile, family income indirectly affected the cases of dengue fever through environmental sanitation and preventive behavior. Family income in its effect on dengue fever cases was related to the choice of place to live, because the place with dense population and housing, inadequate housing materials, and the age of the house played a role in the high distribution of Aedesaegypti mosquitoes (Sallam et al., 2017). House owners with high income tend to live in a better place, which was clean and not dense, they might also tend to pay for cleaning services so that their environmental sanitation was well maintained (Alobuia, Missikpode and Aung, 2015).

Family income in the results of the analysis of this study was related to the preventive behavior of dengue fever. High family income increased preventive behavior. This condition might be caused by several aspects of preventive behavior that require costs, such as the use of mosquito repellent, the maintenance of mosquito repellent plants and larvae or the use of irrigation systems with pipes in the house so that there were no more water reservoirs. The result of this study was in accordance with the statement of PazSoldán et al. (2015), which stated that high socio-economic status was related to prevention practices that required costs, such as mosquito spray.

A clearer correlation between education level and family income with dengue fever cases in this study was described through intermediary variables in the form of attitudes, intentions, preventive behavior, and environmental sanitation.

The level of education and socioeconomic status were related to the knowledge about dengue infection and its preventive behavior. Someone who was attending school for $\geq 7$ years has a tendency to do better preventive practices (Paz-Soldán et al., 2015). In Indonesia, the education period was $\geq 12$ years and family income above the regional minimum wage (RMW) was considered to have better preventive behavior (Kusumawati and Mudigdo, 2016). Meanwhile, knowledge and low level of education significantly affected the poor preventive practice of dengue fever(Saied et al., 2015).

Different findings were presented by Alobuia et al. (2015), who stated that there wasno significant results in the relationship between knowledge or level of education with preventive practices of mosquitoborne diseases. In addition,Alyousefi et al. (2016) stated thatlevel of education and employment was not a bad predictor of dengue preventive behavior, this was due to high literacy rates in the society 
Different from the various previous statements, in this study, the relationship between the level of education and the preventive behavior of dengue fever was an indirect relationship which involved attitude, self-efficacy, and intention factors. The significant effect between the level of education and attitudes on dengue fever was reported by Al-Dubai et al. (2013). Subjects who have a higher level of education tend to have a positive attitude and implement good preventive behavior (Dhimal et al., 2014). In accordance with this result, in this study, the level of education also directly affected the attitude. Subjects with high level of education ( $\geq$ High School) were more likely to have good attitude by 1.05 times than subjects with low level of education.

A positive attitude related to dengue prevention efforts was related to the practice of controlling mosquito larvae regularly (Mohamad et al., 2014; Sayavong et al., 2015). However, having a good attitude did not mean that someone would be motivated to have good behavior (Mayxay et al., 2013). Therefore, the effect of attitudes on the preventive behavior of dengue fever in this study was not assessed directly, but through the intention as an intermediary variable.

The results of the analysis in this study indicated a positive correlation between attitudes and intentions to behave. This was supported by the results of the study done by Harapan et al. (2016), which stated thata good attitude for the prevention of dengue was related to intention which was reflected in the willingness to participate in the research of dengue.The correlation between attitude and intention was also showed by Tickner et al. (2010), based on their study, positive parental attitudes which related to the benefits of immunization were the reliable predictors of the intention to conduct MMR immunization.

A good intention to prevent dengue fever was also supported by self-efficacy. The level of a person's self-efficacy would determine his/her ability to feel, think, be motivated, and behave (Bandura, 1977).

The risk factors for dengue fever observed in this study only included individual and physical environmental factors, while the social environment which also has the possibility to increase the risk of dengue fever has not been accommodated. Nevertheless, this study showed significant results regarding the effect of socioeconomic factors including educational level, family income, individual factors, and environmental factors on dengue fever cases.

The risk of dengue fever cases was decreased with good environmental sanitation and good preventive behavior. Good environmental sanitation was associated with high level of education and high family income. Meanwhile, good preventive behavior for dengue fever was associated with high level of education and income, as well as positive attitudes, and high self-efficacy and intentions.

\section{REFERENCE}

Abeyewickreme WAR, Wickremasinghe, Karunatilake K, Sommerfeld J, KroegerA (2012). Community mobilization and household level waste management for dengue vector control in Gampaha district of Sri Lanka; an intervention study.Pathogens and Global Health, 106(8): 479-87. doi: 10.1179/2047773212Y.oooooooo6o.

Al-Dubai SAR, Ganasegeran K, Mohanad Rahman A, Alshagga MA, Saif-Ali R (2013). Factors affecting dengue fever knowledge, attitudes and practices among selected urban, semi-urban and rural communities in Malaysia. 
Journal of Epidemiology and Public Health (2019), 4(1): 37-46

https://doi.org/10.26911/jepublichealth.2019.04.01.05

Southeast Asian Journal of Tropical Medicine and Public Health, 44(1): 37-49.

Alobuia WM, Missikpode C, Aung M (2015). Knowledge, attitude and practice regarding vector-borne disease in western Jamaica.Annals of Global Health, 81(5): 654-663. doi: 10.1016/j.aogh.2015.08.013.Knowledge.

Alyousefi TAA, Abdul-Ghani R, Mahdy MAK, Al-Eryani SMA, Al-Mekhlafi AM, Raja YA,Shah SA, Beier JC (2016). A household-based survey of knowledge, attitudes and practices towards dengue fever among local urban communities in Taiz Governorate, Yemen.BMC Infectious Diseases. BMC Infectious Diseases, 16: 1-9. doi: 10.1186/s12879-016-1895-2.

Bäck AT, Lundkvist A (2013). Dengue viruses - an overview.Infection Ecology \& Epidemiology, 3(1): 19839. doi: 10.3402/iee.v3io.19839.

Bandura A (1977). Self-efficacy: Toward a unifying theory of behavioral change. Psychological Review, 84(2): 191-215. doi: 10.1037/0033-295X.84.2.191.

Brady OJ. et al. (2014). Mapping the Epidemiology of Dengue, in Gubler, D. J. et al. (eds) Dengue and Dengue Hemorrhagic Fever. 2nd edn. Oxfordshire: CAB International: 30-50.

Calixto OJ, Anaya JM (2014). Socioeconomic status. The relationship with health and autoimmune diseases. Autoimmunity Reviews. Elsevier B.V., 13(6): 641-654. doi: 10.1016/j.autrev.2013.12.002.

Chanyasanha C, Guruge GR, Sujirarat D (2015). Factors influencing preventive behaviors for dengue infection among housewives in Colombo, Sri Lanka. Asia-Pacific Journal of Public Health, 27(1): 96-104. doi: 10.1177/101053-
9514545646.

Cucunawangsih, Lugito NPH (2017). Trends of dengue disease epidemiologyVirology: Research and Treatment, 8. doi: 10.1177/1178122X17695836.

Dhimal M,Aryal KK, Dhimal LM, Gautam I, Singh SP, Bhusal CL, Kuch U (2014). Knowledge, attitude and practice regarding dengue fever among the healthy population of highland and lowland communities in central Nepal. PLoS ONE, 9(7): 1-15. doi: 10.1371/journal.pone.0102028.

Dinas Kesehatan Provinsi Jawa Tengah (2018) Buku Saku Kesehatan Tahun 2017. Semarang. Available at: http://dinkesjatengprov.go.id/v2018/dokum en/bukusaku_2017/mobile/index.ht $\mathrm{ml} \# \mathrm{p}=1$.

Glanz K, Rimer BK, Viswanath K (2008) Health behavior and health education: theory, research, and practice. doi: 10.1016/Soo33-3506(49): 815241.

Guzman MG, Harris E (2015). Dengue, Lancet, 385(9966): 453-465. doi: 10.1016/So140-6736(14)60572-9.

Harapan H, Anwar S, Setiawan AM, Sasmono RT, Aceh Dengue Study. (2016). Dengue vaccine acceptance and associated factors in Indonesia: A community-based cross-sectional survey in Aceh, Vaccine, 34(32): 36703675. doi: 10.1016/j.vaccine.2016.05.026.

Kularatne SAM (2015). Dengue fever, BMJ, 4661: h4661. doi: 10.1136/bmj.h4661.

Kusumawati D, Prayitno A,Dharmawan R (2016). Geographical Satellite and Survey Data for Prediction of Dengue Cases in Sukoharjo, Indonesia.Journal of Epidemiology and Public Health, 1(1): 11-17.

Kusumawati LS, Mudigdo A (2016). Asso- 
ciation between socio-economic factor, home sanitation, sense of belonging, and health behavior, in patients with dengue hemorrhagic fever in Kediri, East Java.Journal of Health Promotion and Behavior, 1(4): 238-243.

Martini M, Sri Yuliawati S, Hestiningsih R, Kusariana N, Purwantisari S (2018). Vector density and sanitation in high dengue hemorrhagic fever endemic area in Tembalang district, Semarang, Central Java, in Revitalizing Family Planning Program and Women's Empowerment for the Improvement of Population Well-being and Economic Development. Surakarta: Masters Program in Public Health, Universitas Sebelas Maret.

Mayxay M, Cui W, Thammavong S, Khensakhou K, Vongxay V, Inthasoum L, Sychareun V, Armstrong G (2013). Dengue in peri-urban Pak-Ngum district, Vientiane capital of Laos: a community survey on knowledge, attitudes and practices.BMC Public Health, 13: 1-8.https://doi.org/10.1186/1471-2458-13-434.

Mohamad M, Selamat MI, Ismail Z (2014). Factors associated with larval control practices in a dengue outbreak prone area.Journal of Environmental and Public Health. Hindawi Publishing Corporation. 1-6. doi: 10.1155/2014/459173.

Nurrochmawati I, Dharmawan R, Pawito (2017). Biological, Physical, Social, and Environmental Factors Associated with Dengue Hemorrhagic Fever in Nganjuk, East Java, Journal of Epidemiology and Public Health, 2(2): 93-105.

Pang T, Mak TK, Gubler DJ (2017). Prevention and control of dengue-the light at the end of the tunnel.The
Lancet Infectious Diseases, 17(3): e79-e87. doi: 10.1016/S1473-3099(16): 30471-6.

Paz-Soldán VA,Morrison AC, Lopez JJC, Lenhart A, Scott TW, Elder JP, Sihuincha M,Kochel TJ,Halsey ES, Astete H, McCall PJ (2015). Dengue knowledge and preventive practices in Iquitos, Peru.American Journal of Tropical Medicine and Hygiene, 93(6): 1330-1337. doi: 10.4269/ajtmh.15-0096.

Rezza G (2012). Aedes albopictus and the reemgernce of Dengue.BMC Public Health, 12: 72.

Saied KG, Al-Taiar A, Altaire A, Alqadsi A, Alariqi EF, Hassaan M (2015). Knowledge, attitude and preventive practices regarding dengue fever in rural areas of Yemen.International Health Advance Access published: 1-6.

Sallam MFFizer C, Pilant AN, Whung PY (2017). Systematic review: Land cover, meteorological, and socioeconomic determinants of Aedes mosquito habitat for risk mapping. International Journal of Environmental Research and Public Health, 14: 1-15. doi: 10.3390/ijerph14101230.

Sayavong C,Chompikul J, Wongsawass S, Rattanapan C (2015). Knowledge, attitudes and preventive behaviors related to dengue vector breeding control measures among adults in communities of Vientiane, capital of the Lao PDR', Journal of Infection and Public Health. King Saud Bin Abdulaziz University for Health Sciences, 8(5): 466-473. doi: 10.1016/j.jiph.2015.03.005.

Shepard DS, Undurraga EA,Halasa YA (2013). Economic and disease burden of dengue in Southeast Asia.PLoS Neglected Tropical Diseases, 7(2). doi: 
Journal of Epidemiology and Public Health (2019), 4(1): 37-46

https://doi.org/10.26911/jepublichealth.2019.04.01.05

10.1371/journal.pntd.ooo2055.

Tickner S, Leman PJ, Woodcock A (2010). The Immunisation Beliefs and Intentions Measure (IBIM): Predicting parents' intentions to immunise preschool children.Vaccine. Elsevier Ltd, 28(19): 3350-3362. doi: 10.1016/j.- vaccine.2010.02.083.

World Health Organization (2018) Dengue and severe dengue. Available at: http://www.who.int/news-room/factsheets/detail/dengue-and-severedengue. 